\title{
Reading: The State of the Discipline
}

\section{Citation}

Price, Leah. 2004. Reading: The state of the discipline. Book History 7: 303-320.

\section{Published Version}

http://dx.doi.org/10.1353/bh.2004.0023

\section{Permanent link}

http://nrs.harvard.edu/urn-3:HUL.InstRepos:2623551

\section{Terms of Use}

This article was downloaded from Harvard University's DASH repository, and is made available under the terms and conditions applicable to Other Posted Material, as set forth at http:// nrs.harvard.edu/urn-3:HUL.InstRepos:dash.current.terms-of-use\#LAA

\section{Share Your Story}

The Harvard community has made this article openly available.

Please share how this access benefits you. Submit a story.

\section{Accessibility}


Reading: The State of the Discipline

Leah Price

When William James wanted to explain "the stupidity and injustice of our opinions, so far as they deal with the significance of alien lives," the example that he chose was reading:

Take our dogs and ourselves, connected as we are by a tie more intimate than most ties in this world; and yet ... how insensible, each of us, to all that makes life significant for the other! - we to the rapture of bones under hedges, or smells of trees and lamp-posts, they to the delights of literature and art. As you sit reading the most moving romance you ever fell upon, what sort of a judge is your fox-terrier of your behaviour? With all his good will toward you, the nature of your conduct is absolutely excluded from his comprehension. To sit there like a senseless statue when you might be taking him to walk and throwing sticks for him to catch! What queer disease is this that comes over you every day, of holding things and staring at them for hours together, paralyzed of motion and vacant of all conscious life? ${ }^{1}$

James's example points to one of the central difficulties of a history of reading: how to analyze an activity that's too close for critical distance, and perhaps for comfort. What's "alien" here is not simply the relation of readers to illiterates (human or canine), but also one reader's relation to another. Writers on reading have lamented its unknowability or savored its ineffability as far back as Wilkie Collins’s 1858 essay “The Unknown Public.” This is the assumption that book historians have come to combat, either in practice (by uncovering the physical gestures and material artifacts which can make one reader knowable to another), or in theory (by tracing the origins of a cartesian dualism which severs reading from the hand and the voice). ${ }^{2}$ For all the polemics that have shaped the field - about extensive reading, about technological determinism, about whether to determine the texts read by a particular demographic group or to define the audience reached by an individual text - historians seem united in the urge to contest James's characterization of reading as a literally "senseless” act.

This doesn't, however, imply any agreement about what the history of reading is. As David Hall has pointed out, different scholars have understood the term to encompass enterprises as various as the social history of education, the quantitative study of the distribution of printed matter, and the reception of texts or diffusion of ideas. ${ }^{3}$ Reading means something different to literary critics (for whom it tends to feed either into case studies focused on the reception of particular texts, or into theories of hermeneutics) than for historians (for whom it can become a subset of social or intellectual history). Among the former, reader response is now an established enough field to have its classics (Janice Radway, Reading the Romance: Women, Patriarchy and Popular Literature [Chapel Hill: U of North Carolina P, 1984]), its historians (Elizabeth Freund, The Return of the Reader: Reader-Response Criticism [London: Methuen, 1987]), its anthologies (The Reader in the Text, ed. Susan Suleiman and Inge Crosman (Princeton UP, 1980) and Reader-Response Criticism: From Formalism to Post-Structuralism, ed. Jane Tompkins [Baltimore: Johns Hopkins UP, 1980]), even its anthology-pieces (Stanley Fish’s “Is There a Text in this Class”) or Robert Darnton’s “First Steps Toward a History of Reading”). Yet reader-response still looks less like a field than a battleground: its manifestations range from structuralist neologism to folksy case studies to mad scientism. (This last culminates in Victor Nell's Lost in a Book [New Haven: Yale UP, 1988], which marries pieties about 
readerly pleasure with a report on readers' salivation rates, cardiovascular responses, and distinctly unpleasant-sounding electrogastrograms). Nor is an interest in reading confined to historicist literary critics. Their formalist colleagues have long saddled the reader with a series of alliterative adjectives: implied, inscribed, intended, ideal. ${ }^{4}$ The relation among these models remains to be theorized. Even the basic distinction between a work's reader and a text's addressee is less commonly accepted than that between author and narrator. A critic as eminent as Tzvetan Todorov, for example, still cavalierly substitutes inscribed readers for empirical audiences, complaining (one hopes tongue-in-cheek) that "One of the difficulties in studying reading is due to the fact that reading is so hard to observe: introspection is uncertain, psychosociological investigation is tedious. It is therefore with a kind of relief that we find the work of construction represented in fiction itself, a much more convenient place for study." 5

Convenient but reductive: in fact, some of the most interesting cases are those in which the implied reader differs sharply from what we know about the empirical audience. Thus, Roger Chartier demonstrates the diffusion of aristocratic letter-writing manuals among peasants in chapbook reprints, while Jonathan Rose reconstructs a working-class audience for the Edwardian public-school yarn; Kate Flint shows that middle-class girls in the same period preferred the Boy's Own Paper to its putatively gender-appropriate spinoff, the Girl's Own; and so on. ${ }^{6}$ The question here is not simply the gulf separating inscribed from implied audience, or even audience from market, but also the relation among the disciplines that study those different phenomena. Only the rare argument that combines historical sensitivity with interpretive ambition, like Garrett Stewart's Dear Reader: The Conscripted Audience in Nineteenth-Century British Fiction (Baltimore: Johns Hopkins UP, 1996), manages to carve out a space (in Stewart's words) "between sociohistorical studies of the popular audience, on the one hand, and so-called reader-response criticism, on the other - between ... purchasing or processing ends": such a middle course, he shows, is the only way to avoid either redefining the text as "an affective structure of effected meaning” or displacing it "from linguistic effect to social artifact” (8).

Part of the problem is that literary critics tend to act as if reading were the only legitimate use of books. They forget that the book can take on a ritual function (even, or especially, for non-literates); it can serve as a gift (Natalie Davis, The Gift in Sixteenth-Century France. [Madison: U of Wisconsin P, 2000] and Jason Scott-Warren, Sir John Harrington and the Book as Gift [Oxford: Oxford UP, 2001]), an investment (Philip Connell,“Bibliomania: Book Collecting, Cultural Politics, and the Rise of Literary Heritage in Romantic Britain” in Representations 71 [2000]:24-47), even an engineering challenge. ${ }^{7}$ As long ago as 1968, Jack Goody's edited volume Literacy in Traditional Societies (Cambridge UP) highlighted the role that literacy plays even in those cultures which earlier scholars had assumed to be insulated from the written word. The place of reading within anthropology today can be gauged from a very different collection, Jonathan Boyarin's The Ethnography of Reading (Berkeley: U of California P, 1992), which brings together case studies from ancient and modern Israel, Anglo-Saxon England, pre-modern Japan, contemporary Indonesia and Colombia, upper-middle-class neighborhoods in Texas and an Indian reservation in California, as well as a theoretical overview by Johannes Fabian with excurses on the role that transcription and writing more generally play in fieldwork. Elizabeth Long's unabashedly populist chapter, “Textual Interpretation as Collective Action," uses an analysis of contemporary reading groups to counterbalance the traditional trope of solitary reading. Empirical studies of mid-twentieth-century American adults 
have shown that reading correlates with social involvement: readers need others to set an example, to provide a sounding-board for reactions to texts, to recommend and criticize and exchange books. Long's emphasis on the influence of oral and communal interactions on what's been imagined for several centuries as a silent and solitary activity thus inverts Natalie Davis's exhortation for critics to "consider a printed book not merely a source for ideas and images, but a carrier of relationships." 8

This is as true of book historians as of anyone else: here, then are some thoughts on recent developments in the field, inevitably skewed by the occupational blind spots of a cardcarrying Victorianist literary critic. (Any history of reading is also a meditation on the reading of a particular writer.) If one took readership seriously, one could organize a review essay like this not by topic, but by audience: scholarly monographs, edited collections, trade books, massmarket anthologies, digital databases. Even within the first of those categories, studies of reading take a variety of forms: some are organized around a particular reading public (Kate Flint's The Woman Reader, Jonathan Rose's The Intellectual Life of the British Working Classes, and Jacqueline Pearson's Women's Reading in Britain, 1750-1835 [Cambridge: Cambridge UP, 1999]), others around a category of book (Radway's Reading the Romance), still others around a particular form of evidence (H.J. Jackson, Marginalia: Readers Writing in Books. [New Haven: Yale UP, 2001]). A historiography of reading could also categorize books according to the disciplinary affiliations of their readers. A study addressed to literary critics (like Problèmes actuels de la lecture, ed. Lucien Dällenbach and Jean Ricardou [Paris: ClancierGuenaud, 1982], which makes up in neo-structuralist diagrams for what it lacks in quantitative tables) differs recognizably from one addressed to historians (for example, David Vincent's Literacy and Popular Culture: England 1750-1914 [Cambridge UP, 1989]) or to social scientists (Brian V. Street's Literacy in Theory and Practice [Cambridge UP, 1984] and Harvey Graff's The Literacy Myth [New York: Academic P, 1979]) or psychologists such as Victor Nell. Yet as far as their inscribed reader goes, all of these have more in common with each other than with a popular study such as Alberto Manguel's A History of Reading (London: HarperCollins, 1996), a series of bravura meditations that wear their learning lightly. In turn, Steven Roger Fischer's $\underline{A}$ History of Reading (London: Reaktion, 2003) shares little more than its title with its predecessor. The wider geographical scope of this second History of Reading may explain its breathless pace, but not its portentous tone or one-sentence paragraphs: where Manguel marries the essayistic with the encyclopedic, Fischer yokes platitudes with typos. Teachers looking for a class text on the history of reading may prefer to supplement Manguel with the relevant essays in The Book History Reader, edited by David Finkelstein and Alistair McCleery (London: Routledge, 2002). ${ }^{9}$

To act on Meredith McGill's argument that "unauthorized reprinting makes publication distinctly legible as an independent signifying act," ${ }^{10}$ we might add another category: recent reprints of older books in the field, especially Richard Altick's The English Common Reader: A Social History of the Mass Reading Public, 1800-1900 (Chicago: University of Chicago Press, 1957; reprinted with a preface by Jonathan Rose [Columbus: Ohio State University Press, 1998]) and Q. D. Leavis, Fiction and the Reading Public, 1932, reprinted with an introduction by John Sutherland (London: Pimlico, 2000), as well as the collected work of the now curiously dated Holbrook Jackson (The Anatomy of Bibliomania, The Reading of Books, and The Fear of Books, all U of Illinois P, 2001). As a third taxonomy, however, we could distinguish 
monographs from anthologies, essay collections, and of course the eponymous "readers." Some of these are organized by author: thanks to the University of Massachusetts Press series in book history, scattered essays have been assembled in volumes such as David Hall's Cultures of Print: Essays on the History of the Book (1996) and D.F. McKenzie's Making Meaning: 'Printers of the Mind' and Other Essays (2002). But the field has been defined most decisively by multiauthor collections. Reading in America, edited by Cathy Davidson (Baltimore: Johns Hopkins UP, 1989) juxtaposes essays whose methodological reflections have much to teach nonAmericanists (especially Davidson's introduction and Robert Darnton's "What is the History of Books?”) with reader's digests of several important monographs in the field (Davidson's own Revolution and the Word, for example, and Janice Radway's study of the Book-of-the-Month Club).

Based on conference proceedings rather than on previously published sources, The Practice and Representation of Reading in England (Cambridge UP, 1996), edited by James Raven, Helen Small, and Naomi Tadmor, assembles trailers for (and outtakes from) several equally important recent monographs, including William Sherman's John Dee: The Politics of Reading and Writing in the English Renaissance (Amherst: U of Massachusetts P, 1995) and a characteristically dense chapter on the physiology of reading drawn from Adrian Johns' The Nature of the Book (Chicago: U of Chicago P, 1998). The volume also includes provocative studies of particular readers (John Brewer on an eighteenth-century culture vulture), oeuvres (Kate Flint on the inscribed reader in Thackeray) and audiences (Helen Small's tour de force on Dickens's public readings). Histoires de la lecture (Paris: Maison des Sciences de l'homme, 1993) and Pratiques de la lecture (Marseille: Rivages, 1985) bear the editorial stamp of Roger Chartier, also a force behind two more general multi-volume collections which have much to say about reading, the Histoire de la vie privée and Histoire de l'édition francaise. Its origins in a conference may explain the asymmetrical organization of Histoires de la lecture: its first half consists of variably ambitious surveys of national traditions (Spanish, Dutch, Italian, German, English, American, Russian), while the second contains more focused discussions of methodological problems such as the relation of the history of reading to the history of the book (Jean-Yves Mollier) and to the history of literature (Jean-Marie Goulemot).

Despite Darnton's insistence that "books do not respect limits, either linguistic or national" - a maxim substantiated by case studies like Elizabeth Eisenstein's Grub Street Abroad (Oxford UP 1992) - most of those collections are national in scope. The case is different for single-authored works, which have focused increasingly on movements across national or colonial borders. Where "circulation" was once a metaphor for the transmission of ideas, recent books by James Raven, Priya Joshi, and Franco Moretti have conspired to remind us just how literally books circulate in space. ${ }^{11}$ (The history of the book is also a geography of the book.) But reference works and encyclopedic essay collections still tend to take a single nation as their topic, even when - as in Readers in History: Nineteenth-Century American Literature and the Contexts of Response, edited by James L. Machor (Baltimore: Johns Hopkins UP, 1993) - they have implications for other case studies. Others limit their focus chronologically, as in Books and Their Readers in Early Modern England, ed. Jennifer Andersen and Elizabeth Sauer (Philadelphia: University of Pennsylvania Press, 2002); Reading, Society and Politics in Early Modern England, ed. Kevin Sharpe and Steven Zwicker (Cambridge: Cambridge UP, 2003); Isabel Rivers's Books and Their Readers in Eighteenth Century England: New Essays 
(Continuum, 2002), a sequel to her earlier Books and Their Readers in Eighteenth Century England (New York: St Martin's P, 1982); and John O. Jordan and Robert L. Patten's Literature in the Marketplace: Nineteenth-Century British Reading and Publishing Practices (Cambridge UP, 1995), a collection that manages to place Simon Eliot's charts and graphs in dialogue with J. Hillis Miller's deconstructive reading of a fictional valentine.

In contrast, neither space nor time limits A History of Reading in the West, edited by Guglielmo Cavallo and Roger Chartier and translated by Lydia G. Cochrane (1999). International not only in its coverage but in its authorial makeup and publication history (translated from a Franco-Italian coproduction and co-published in Britain by Polity and in the U.S. by the University of Massachusetts Press), this volume collects newly commissioned essays that speak to students and specialists. Taken together, the chapters trace a rough chronological progression, from silent reading in classical Greece to the emergence of the codex in the Roman world to medieval reading techniques (there are chapters on scholasticism and Jewish reading communities, as well as M.B. Parkes on graphic conventions and Paul Saenger on silent reading). The one constant across this encyclopedic range is the progressive disappearance of the reader's body. Thus, Guglielmo Cavallo's "Between Volumen and Codex: Reading in the Roman World" describes classical medical works which include reading among healthful forms of physical exercise (75). The volumen had to be held with both hands (only the codex would liberate one hand so that writing could accompany reading); the body participated as much as the voice. $^{12}$ In Paul Saenger's account, however, word separation, word order and syntactic punctuation enabled silent reading, which engendered heterodoxy in turn. Armando Petrucci's concluding chapter brings this narrative up to the present, showing that the emergence of the public library has trained readers to efface their own bodies: the proper thing to put on tables is books, not feet; pages must not be touched with dirty hands or with gummy fingers. But Petrucci's survey also steps back far enough to question triumphalist celebrations of the spread of literacy. Although book production has been boosted rather than challenged by the growth of new media, UNESCO figures show that only half of that production occurs outside of Europe; and while literacy rates are gradually rising, in absolute terms the number of illiterates is continually growing. As we learn in Martyn Lyons's chapter "New Readers in the Nineteenth Century: Women, Children, Workers," the first generation to accede to mass literacy (at the end of the nineteenth century) was also the last to see the book unchallenged as a communications medium. This volume contains other stories as well: Anthony Grafton's witty analysis of the material conditions of humanists' reading; Dominique Julia on literacy and illiteracy in the Counter-Reformation; Reinhard Wittmann re-opening the debate about whether intensive reading really gave way to extensive at the end of the eighteenth century. Throughout we can see the places of reading change, from the open spaces of antiquity (gardens, porticoes, squares, streets) to the closed sites of the Middle Ages (churches, monks' cells, refectories, courts). But reading practices reshape those spaces in turn: silent reading carved out privacy within communal institutions such as the coffee shop, the public library, and the railway carriage. (Which of us has not used a newspaper, or a copy of Book History, as a shield?)

All that unites the case studies that make up A History of Reading is a fascination with ways of reading that now appear marginal or even unthinkable - most prominently, various forms of vocalization. Book historians' interest in reading aloud bears two allegorical charges. ${ }^{13}$ One is that the scene of one person reading to others restores a social dimension to an activity 
now more often parsed as individual or even individualistic. The Roman reader standing up and using hand gestures (an emblem in Cavallo's chapter in A History of Reading) or a lector declaiming pages of The Count of Monte Cristo in a Cuban cigar factory (Manguels' most engaging character) stand opposite the solitary, silent reading that contemporary academics idealize and intermittently practice. In reconstructing sociable forms of reading, book historians make one reader knowable to another.

Even the genre which most powerfully allies writing with individual freedom - the American slave narrative - reminds us that literacy is inherently a social skill. When Douglass's mistress teaches him to spell words of three or four letters, her husband "forbade her to give [him] any further instruction." That prohibition confirms our culture's triple association of literacy with upward mobility, with spiritual liberation, and with political progress (a myth that even Levi-Strauss hardly dented). What comes next is less often quoted: "the determination which he expressed to keep me in ignorance only rendered me the more resolute to seek intelligence. In learning to read, therefore, I am not sure that I do not owe quite as much to the opposition of my master as to the kindly assistance of my amicable mistress." Michael Warner's The Letters of the Republic: Publication and the Public Sphere in Eighteenth-Century America (Cambridge: Harvard UP, 1990) insists that reading was not just a neutral medium which whites happened to monopolize, but rather a defining feature of white identity - and one which depended crucially on the illiteracy of blacks. Like literacy, illiteracy fulfills a social function. Social, but also sociable. David Henkin's City Reading: Written Words and Public Spaces in Antebellum New York (New York: Columbia UP, 1998) deploys "unobtrusive street signs, imposing commercial advertisements, incendiary political broadsides” (x) as an emblem of how little of the world's reading actually takes place in private. As Henkin points out, our own association of reading with privacy feeds into "a cluster of myths, some of which romanticize the written word, others of which romanticize a preliterate world of oral communication” (6). Yet reading in nineteenth-century New York was just as likely to take place outdoors as indoors - in the same way that our reading today can take place in airports or doctors' waiting rooms.

Scholars working on reading have sometimes imagined their field as more pluralistic, more democratic, or somehow more transgressive than the study of authorship. (Robert Gross has cautioned against imagining the history of reading as "a Whiggish contest between liberty and power"; as James Secord puts it in his massively researched Victorian Sensation, "a critical emphasis on fragmentation and interpretative freedom has sometimes slipped into a celebration of the Victorian values of liberal pluralism ... accounts of audience response illustrate diversity, but little else.”14 ) Others see themselves as puncturing a traditional consensus which showed more interest in writing than in reading: one active, the other reactive; one originary, the other belated. It's true that any simple opposition between productive writers and passive readers has given way to a new consensus that readers make meaning. Jean Marie Goulemot summarized the new orthodoxy when he declared that "to read is to constitute a meaning, not to reconstitute one”(“Lire un tableau: Une lettre de Poussin en 1639” in Pratiques de la lecture, 91, my translation).

Such a narrative would not be entirely unfounded: certainly it's possible to see ours as an age of readers. Within literary criticism proper, the reception theory that flourished in the German-speaking world in the 1970s shifted the making of meaning from authors to readers; so 
did Stanley Fish's interest in “communities” which determine (or at least allow us to predict) readers' responses - but also, just as importantly, in the unfolding of a single reader's response through time. Fish's innovation was not simply to replace the author with the reader as a maker of meaning, but also, more subtly, to substitute a temporal act (reading) for a spatial object (the text). Arguing against those New Critics who dismissed the reader's activities as "the disposable machinery of extraction," Fish redirected attention to "the developing responses of the reader to the words as they succeed one another on the page: the making and revising of assumptions, the rendering and regretting of judgments, the coming to and abandoning of conclusions, the giving and withdrawing of approval, the specifying of causes, the supplying of answers, the solving of puzzles." Fish gives the "making” in "making sense” its most literal force: the consumer also produces meaning.

Even outside of reader-response theory itself, literary critics' basic unit of measure has become consumption, not production. Where earlier feminists discussed texts about women or texts by women, scholars now are as likely to discuss what Edwardian girls made of the selfproclaimed boys' books that they borrowed from their brothers. And that shift from authorship to readership extends outward to popular culture. Even in the turn-of-the-millennium paperback industry, the shift from reprint series based on authors' identity (such as Virago) to others based on readers' identity (such as Oxford Popular Classics, made up largely of turn-of-the-century bestsellers) reflects a new emphasis on consumers as agents.

Yet such a Whig history also risks overstating the novelty of reader-response criticism, for wherever you look in history, the reader, like the novel and the middle class, always seems to be rising. The wealth of work on readership in eighteenth-century Britain (including the work by Rivers, Brewer and Pearson already mentioned) reflects that century's pivotal role in the shift from a criticism based on production to one focusing on consumption. Trevor Ross's The Making of the English Literary Canon: From the Middle Ages to the Late Eighteenth Century (Montreal: McGill-Queen's University Press, 1998) has re-examined a whole range of issues, from copyright to canonization, in light of this new interest in the circulation of cultural commodities. In contrast, Regenia Gagnier's The Insatiability of Human Wants (Chicago: University of Chicago Press, 2000) situates that shift a century later, juxtaposing the rise of the reader with the development of microeconomics as twin manifestations of a new interest in consumption. Rather than seeing some cultures as author-centered and others as reader-focused, then, it may be safer to say simply that the relation of reading to writing varies by time and place. (The theory of imitatio once bound them together more tightly than today's creative writing courses do.) David Hall has shown that in eighteenth-century New England reading was taught before writing, and the situation is similar elsewhere in the early modern West. ${ }^{15}$ We tend to think of reading as connoting passivity, but Kevin Sharpe reminds us that patronage and its paratextual corollaries such as the dedication - place the reader in a position of greater power than the writer. ${ }^{16}$

Book historians have a vested interest in the interplay of reading with writing, for writing about reading and writing while reading are among the best sources that we have. One produces external evidence (in genres ranging from autobiographies to inquisitorial records); the other generates internal evidence (marginalia, commonplace-books). Traces of reading practices can also take non-verbal and even non-bibliographical forms, however: we have as much to learn 
from the layout of libraries and bookshops as from furniture like the reading wheel which allowed humanists to compare and collate passages from different books.

Familiarity makes reading appear deceptively knowable: it's part of the daily experience of any historian or literary critic. But scholars are also well-positioned to know how easily reading can become a self-consuming act. The most impassioned reading destroys its own traces. The greater a reader's engagement with the text, the less likely he or she is to pause long enough to leave a record: if an uncut page signals withdrawal, a blank margin just as often betrays an absorption too rapt for note-taking. Can a book mark us if we mark it?

As a result, studies drawing on autobiography or marginalia alike are biased toward certain kinds of readers and styles of reading. Conversely, projects such as the Reading Experience Database (http://www.open.ac.uk/Arts/RED/), which combats this problem by assembling "evidence from lives in which reading appears to have been peripheral," are inevitably opportunistic in their cherry-picking of decontextualized "reading experiences" from sources whose own structure and content differ widely. Michel de Certeau compared readers to poachers, but historians of reading may be more like magpies. ${ }^{17}$

Yet that miscellaneity can also be an advantage. Scholars in the field have culled sources as various (in Jonathan Rose's words) as "memoirs and diaries, school records, social surveys, oral interviews, library registers, letters to newspaper editors, fan mails, and even the proceedings of the Inquisition” (1). The Reader Revealed, edited by Sabrina Baron (Washington: Folger Shakespeare Library, 2001) draws inferences about reading from marginalia, but also "from the kinds of reading readers received; from the dominant texts of the culture and the ways they were presented, distributed, and used; and from the paratexts of early modern books - frontispieces, tables, commendatory verses, indices, plates, and, most intriguingly, those dedications and addresses in which writers, publishers, and printers at once imagined and conjured the early modern patron, reader, and marketplace for books” (13).

Part of the question is what exactly such texts and artefacts form evidence for. The title of an important recent collection, The Practice and Representation of Reading in England, suggests the fundamental gap which differentiates sociohistorical studies of literacy from arthistorical or literary-critical studies of the motif of the reader. (Or novelistic ones: Don Quixote can stand as the first in this line.) Yet those works which attempt to reconstruct the former are inevitably products - even manifestations - of the latter. Some of the most persuasive recent studies are those which face up to the constructed nature of their evidence. Exemplary in this respect is Kate Flint's The Woman Reader, which marshals an dizzying range of representations of women's reading -- visual and verbal, descriptive and prescriptive. (Flint points out how many of the latter focus on what not to read: the energies of Victorian social criticism are characteristically negative.) Avoiding the temptation to flatten out her sources, Flint takes the time to think about why women's reading should be celebrated in particular genres (autobiography, for example) and attacked in others (medical and psychological manuals). If men's reading was associated with the mind, she shows, women's reading was tarnished by association with the body.

While Annaliste social historians like François Furet and Jacques Ozouf concentrated on large-scale quantitative studies, to shift our attention from authors to readers does not necessarily mean moving from the individual to the mass. ${ }^{18}$ Case studies of particular individuals have been central to the field from the very beginning (witness Ginzburg's The Cheese and the Worms 
(Baltimore: Johns Hopkins UP, 1980) and Darnton’s “Readers respond to Rousseau”). In "Studied for Action: How Gabriel Hervey Read his Livy," Past and Present 129 (November 1990): 30-78, Lisa Jardine and Anthony Grafton tease an extraordinary number of inferences out of the marginalia to Hervey's History of Rome. Hervey returned to this text over and over between 1568 and 1590, reading the same text in different ways at different moments in order to perform services for present or potential patrons. Hervey's habits pose a challenge to later conceptions of reading as self-directed and disinterested - even if twenty-first century academics should be well placed to understand reading as a mode of career advancement. (Today, an inflight advertisement for audio summaries of business books claims that "just as there are personal trainers for your body ... think of us as your 'personal reader' to advance your career”). Kevin Sharpe's Reading Revolutions (New Haven: Yale University Press, 2000), too, works outward from the diary, commonplace-books and library of a seventeenth-century English landowner. And the reading of individual writers forms the starting-point of Robert DeMaria's Samuel Johnson and the Life of Reading (Baltimore: Johns Hopkins UP, 1997), Brian Stock's After Augustine : the Meditative Reader and the Text (Philadelphia: U of Pennsylvania P, 2001), and William Sherman's John Dee: The Politics of Reading and Writing in the English Renaissance.

But this model has also extended to studies of groups of readers. Janice Radway’s Reading the Romance launched a movement whose influence can still be seen in recent studies such as Elizabeth McHenry's Forgotten Readers: Recovering the Lost History of African American Literary Societies (Durham: Duke UP, 2002). Indeed, some of the most interesting recent work on nineteenth-century American women's reading - that of Barbara Hochman and Mary Kelley, for example - has stressed precisely the impossibility of separating individual reading practices from literary communities. From a slightly different angle, Jon Klancher's The Making of English Reading Audiences, 1790-1832 (Madison: U of Wisconsin P, 1987) argues that "the intense cultural politics of the Romantic period obliged writers not only to distinguish among conflicting audiences, but to do so by elaborating new relations between the individual reader and the collective audience" (11). And Patrick Brantlinger's The Reading Lesson: The Threat of Mass Literacy in Nineteenth-Century Britain (Bloomington: U of Indiana P, 1998) argues that the heuristic distinction between a singular addressee and a multifarious public in itself responds to anxieties about the mass public.

It's appropriate, in this context, that several studies use library records as a clue to the reading habits of their patrons: scholars of British history, for example, can consult Simon Eliot's A Measure of Popularity: Public Library Holdings of Twenty-Four Popular Authors, 1883-1912 (London: History of the Book On-Demand Series 2, 1992) or Jan Fergus's "Eighteenth-Century Readers in Provincial England: the Customers of Samuel Clay's Circulating Library and Bookshop in Warwick, 1770-1772," Papers of the Bibliographical Society of America 78:2 (1984). But such instrumental mining of library records needs to be distinguished from studies of the library itself as a social institution, either theoretical - in R. Howard Bloch and Carla Hesse's Future Libraries (Berkeley : U of California P, 1995) - or synoptic (e.g., Histoire des bibliothèques françaises, ed. André Vernet [Paris: Promodis-Editions du Cercle du librairie, 1988-] or Alastair Black’s A New History of the English Public Library ... 1850-1914 [London: Leicester UP, 1996]).

As an early generation of polemicists acknowledged - Q.D. Leavis comes to mind, but so 
does Richard Hoggart's The Uses of Literacy, first published in 1957 and still in print - the question of what people at some distant historical moment read rarely lies very far from the question of what people here and now should read. The success of Jonathan Rose's Intellectual Life of the British Working Classes - the only recent book other than Manguel's to reach the kind of serious general audience for which it forms an elegy - suggests how live those debates remain. Not the least of the achievements of this loose, baggy monster is Rose's attack on recent culture warriors' unexamined assumption that the task of widening access to culture is coextensive with the enterprise of broadening the canon. Pointing out that multiculturalist critics more often project their own concerns onto a hypothetical mass audience than excavate the desires of that audience itself, The Intellectual Life asks what books influenced working-class readers - but also, just as interestingly, what books didn't. (Marx is prominent in the latter category.) Drawing on questionnaires, oral histories, library records and above all memoirs, Rose's richly researched project exemplifies both the power and the limits of autobiographical evidence. "Memoirists are not entirely representative of their class," Rose acknowledges, "if only because they were unusually articulate." His introduction discounts "bowlderization" on the grounds that most of these autobiographies were unpublished or self-published, but this is to ignore that authors can alter evidence themselves as easily as their publishers can. Not only are autobiographers by definition highly literate, but the dominance of rags-to-riches stories (not just in autobiographies in surveys of Labor MPs) makes it hard for the adult narrator not to read his middle-class milieu backward into the experiences of the working-class youth described. Can a person - or a culture - be trusted to self-diagnose its reading habits?

In short, as Robert Darnton wrote in his often-reprinted "What is the History of Books?", "reading remains the most difficult stage to study in the circuit that books follow." Depressingly, much of what we know about standards for evidence is negative. Bowman and Woolf point out that studies of literacy are more notable for the generalizations that they debunk than for those that they develop. The received wisdom has been replaced by received skepticism: literacy is not a single phenomenon that can be studied across different cultures; it does not in itself cause social progress or economic growth, or (at an individual level) social mobility or rationality; "literates do not necessarily think differently from illiterates, and no Great Divide separates societies with writing from those without it."19 In Reading and the Social Order: Reading and Writing in Tudor and Stuart England (Cambridge UP, 1980), David Cressy cautions scholars against taking Tudor writing-masters and preachers as reliable narrators: by definition, such occupations have a vested interest in exaggerating the centrality of literacy within their culture. The strength of the academic study of literacy (self-reflexivity) is inseparable from its weakness (narcissism). ${ }^{20}$

It's telling, in this context, that the two most striking essays in David Resnick's Literacy in Historical Perspective (Washington: Library of Congress, 1983) debunk received wisdom: Thomas Laqueur's, on reading in eighteenth- and nineteenth-century England, questions triumphalist theories of literacy as an index to social progress, while M.T. Clanchy's cautions against technological determinism by showing how many of our assumptions about literacy and the book predate the invention of print. Of the same vintage is Gerd Baumann's The Written Word (Oxford UP, 1986), which reprints classic essays on literacy by Walter Ong and Keith Thomas, among others.

Literary critics have long taken their own immersion in print culture too much for granted 
to discuss literacy as such. Some of the most sophisticated recent work on literacy is selfreflexive, taking its subject to encompass not just literacy itself but successive endeavours to chart and promote it. David Vincent's Literacy and Popular Culture: England 1750-1914 reads literacy as part of a larger history of nationalism, of centralization, and of statistical method itself. $^{21}$ Provocatively, Vincent declares that the self-educated reader is as much of a myth as the self-made millionaire: the long-standing association of reading with autonomy or personal liberation should not blind us to the extent to which reading is communally learned and used. (This may be true in part because the value of literacy commanded such a wide cross-class consensus in Britain by mid-century, at least in theory; in the slave-holding American South, matters were rather different.)

If literacy risks being taken for granted by literary critics, for historians the problem may be the reverse: as David Cressy argues, "scholars ... in a modern mass-literate society .. risk being misled by our own high valuation of literacy into misunderstanding its place, or its absence, in the world we have lost." Cressy nuances such work by insisting that the differential distribution of literacy is more interesting than the effects of literacy itself: like so much else, literacy is a system of differences. In "Labourers and Voyagers," Chartier insists that the distinction between literacy and illiteracy does not exhaust the range of different relationships to writing. On the contrary, as literacy spreads across societies, how and what people read replaces whether they read as a mark of social status. For the historian, then, the issue becomes what Chartier elsewhere calls "contrasting uses of shared objects or competences.",22

The paradigmatic case of those contrasting uses may be the shift from intensive to extensive reading first hypothesized by Rolf Engelsing. Engelsing's description of a lateeighteenth-century shift from the rereading of a few prized texts to the consumption of many ephemeral ones will be familiar to most readers of this journal. ${ }^{23}$ Before that time, Engelsing argues, people of all social classes owned a few books that they read "intensively": slowly, repeatedly, reverently. The classic example of such reading would be the Bible: a book read year after year, never outdated, but paradoxically linked via inscriptions on the flyleaf with the passage of time in readers' own lives. Toward the end of the eighteenth century, in Engelsing's account, the proliferation of new books gave rise to a model of "extensive” reading - skimming and skipping, devouring and discarding - from which we have yet to emerge.

Like the shift from vocalization to silent reading, Engelsing's historical model has been extensively discussed and intensively criticized. ${ }^{24}$ (It's also been substantiated in other national contexts, such as New England in William Gilmore-Lehne's Reading Becomes a Necessity of Life (Knoxville: U of Tennessee P, 1989) as well as, more skeptically, in David Hall's “The Uses of Literacy in New England: 1600-1850," in Printing and Society in Early America, 1-47. Few historians dispute the changes in the production and circulation of books on which Engelsing's thesis rests - the contrast between a backlist of books passed from generation to generation and a cycle of fashionable ephemera as soon outdated as an old newspaper - but their consequences for reading are less clear. Some genres - particularly the novel - appear to have elicited a newly intensive reading at precisely the historical moment to which Engelsing traces its decline: witness Darnton's use of fan mail to reconstruct readers' self-consciously intense engagement with La Nouvelle Héloïse. In fact, the very distribution mechanisms which Engelsing blames for the spread of extensive reading appear to have been perfectly compatible with reverent re-reading: the connection readers felt with Rousseau is precisely what allowed 
booksellers to turn a profit by renting out his novel by the hour. ${ }^{25}$ From a different angle, Cathy Davidson has called attention to the moral overtones of Engelsing's narrative, revealing the hypothesis of a "reading revolution" as the story of a fall. Such a contrast between reverent readers and passive consumers, she argues, fuels a conservative distaste for modern mass culture and mass markets.

This is not to say that anyone questions the distinction between "intensive" and "extensive" reading practices; rather, what's at issue is the extent to which that contrast can be plotted onto a chronological axis. Where Engelsing distinguished mutually exclusive practices, his critics see a repertoire of styles which readers could switch on and off at will. Elizabeth Eisenstein uses the example of early-eighteenth-century journals to argue that rather than one mode of reading replacing the other, both co-exist in any given historical moment. Eisenstein quotes Francis Bacon - "some books are to be tasted, others to be swallowed and some few to be chewed and digested" - but takes his aphorism one step farther, showing that a single book could be read extensively by one reader and intensively by another. ${ }^{26}$ Or, indeed, by the same reader in a different context: a point that resonates with the lived experience of most book historians, who (like Samuel Johnson in Robert DeMaria's account) shuttle daily and even hourly between both styles of reading.

Contra William James, what makes reading hard to study is not (or not only) that it's alien: the complementary challenge is to establish any critical distance from a field whose message is also its medium. Peter Stallybrass's recent work on how early modern readers navigated the codex - a history of reading encapsulated by the bookmark - brings exotic gestures close to home. Redefining the book from a container of meaning to an occasion for operations both mental and manual, his analysis shows the intellectual implications of physical forms; our own culture relegates "study skills" to the remedial classroom, but an essay like Ann Blair's “Annotating and Indexing Natural Philosophy” makes clear that the Post-It note has a long history. ${ }^{27}$ For all its interest in marginalia and marginalized persons, the history of books is centrally about ourselves. It asks how past readers have made meaning (and therefore, by extension, how others have read differently from us), but it also asks where the conditions of possibility for our own reading come from. 
1. William James, "On a Certain Blindness in Human Beings" (1899), in Selected Papers on Philosophy (London: Dent, 1917), 1-21. Thanks to Melisssa Shields for help with the research for this article.

2. For a critique of this model, see David Henkin, "Solitary, Intimate and Exclusive: The Myth of Private Reading” (unpublished paper, 2002).

3. "Readers and Reading in America: Critical Perspectives," in Cultures of Print: Essays on the History of the Book (Amherst: U of Massachusetts P, 1996), 169-88.

4. Wolfgang Iser, The Implied Reader [Baltimore: Johns Hopkins UP, 1974]; Wayne Booth, The Rhetoric of Fiction [Chicago: U of Chicago P, 1961]); Gérard Genette, Figures III [Paris: Seuil, 1972]).

5. Tzvetan Todorov, "Reading as Construction," in The Reader in the Text, ed. Susan Suleiman and Inge Crosman (Princeton UP, 1980), 78-9.

6. Flint, Kate. The Woman Reader, 1837-1914 (Oxford: Clarendon P, 1993). Rose, Jonathan. The Intellectual Life of the British Working Classes. (New Haven: Yale UP, 2001). Chartier, Roger. “Des `secrétaires' pour le peuple? Les modèles épistolaires de l'ancien régime entre littérature de cour et livre de colportage” in La correspondance : les usages de la lettre au XIXe siècle, Roger Chartier, Alain Boureau, et al, eds. (Paris: Fayard, 1991), 159-278.

7.Henry Petrowski, The Book on the Bookshelf (New York: Knopf, 1999).

8. Natalie Davis, Society and Culture in Early Modern France (Stanford UP, 1975), 192.

9. For a fuller discussion of this anthology, see my "Tangible Pages," London Review of Books 24 (31 October 2002): 36-39.

10.Meredith McGill, American Literature and the Culture of Reprinting, 1834-1853

(Philadelphia: U Pennsylvania P, 2003), 5.

11. James Raven, London Booksellers and American Customers: Transatlantic Literary Community and the Charleston Library Society, 1748-1811. (Columbia: U of South Carolina P, 2002); Priya Joshi, In Another Country: Colonialism, Culture, and the English Novel in India. (New York: Columbia UP, 2002); Franco Moretti, Atlas of the European Novel 1800-1900. (London: Verso, 1998).

12. On the role of embodiment in reading, see also Georges Perec, "Lire: esquisse socio-physiologique," Esprit 44 (January 1976): 9-20.

13. For this interest, see, e.g., Roger Chartier and Pierre Bourdieu, "Comprendre les pratiques culturelles,” in Pratiques de la lecture, Roger Chartier, ed. (Marseille: Rivages, 1985), 218-39; 219-20. 
14. Robert Gross,"Seeing the World in Print," unpublished lecture; James A. Secord, Victorian Sensation: The Extraordinary Publication, Reception, and Secret Authorship of Vestiges of the Natural History of Creation (Chicago: U of Chicago P, 2000), 521.

15.David Hall, "Introduction: The Uses of Literacy in New England, 1600-1850," in Printing and Society in Early America, ed. William Joyce, et al. (Worcester: American Antiquarian Society, 1983), 24.

16. Reading Revolutions (New Haven: Yale University Press, 2000), 40.

17. Michel de Certeau, The Practice of Everyday Life, trans. Stephen F. Rendall (Berkeley: University of California Press, 1984), 174.

18. François Furet, Reading and Writing: Literacy in France from Calvin to Jules Ferry (Cambridge UP, 1982).

19. Alan K. Bowman and Greg Woolf, "Literacy and Power in the Ancient World," in Literacy and Power in the Ancient World, ed. Alan K. and Greg Woolf Bowman (Cambridge UP, 1994), 2-3.

20.Bowman and Woolf, "Literacy and Power," 1.

21. For a narrower account of the growth of literacy in nineteenth-century Britain, see David Mitch, The Rise of Popular Literacy in Victorian England (Philadelphia: U of Pennsylvania P, 1992).

22. Roger Chartier, "Labourers and Voyagers," The Book History Reader, ed. David Finkelstein and Alistair McCleery (London: Routledge, 2002), 47-59; Chartier, Correspondance, 9, my translation.

23. See, e.g, Rolf Engelsing, "Die Perioden der Lesergeschichte in der Neuzeit," Archiv für geschichte des Buchwesens 10 (1970): 945-1002.

24. See, e.g., Reinhard Wittmann, "Was there a Reading Revolution at the End of the Eighteenth Century?" in A History of Reading in the West, Guglielmo Cavallo and Roger Chartier, eds (Amherst: U of Massachusetts P, 1999): 284-312.

25. Robert Darnton, "Readers Respond to Rousseau," in The Great Cat Massacre and othe Episodes in French Cultural History (London: Allen Lane, 1984), 215-56.

26. Elizabeth Eisenstein, Grub Street Abroad (Oxford: Clarendon Press, 1992), 49; Davidson, Revolution and the Word, 69-79; Darnton, "Readers Respond to Rousseau,"249-52; Reinhard Wittmann, "Was there a Reading Revolution at the End of the Eighteenth Century?,” 284-312.

27. See Peter Stallybrass, "Books and Scrolls: Navigating the Bible," in Books and Readers in Early Modern England, ed. Jennifer Andersen and Elizabeth Sauer (Philadelphia: U of 
Pennsylvania P, 2002) 42-79; and Ann Blair, "Annotating and Indexing Natural Philosophy," Books and the Sciences in History, ed. Marina Frasca-Spada and Nick Jardine (Cambridge UP, 2000), 70-89. 